\title{
Anti-Microbial Peptides and Their Speculative Role in Periodontitis
}

\author{
Vinita Ved ${ }^{1}$ and Gabriela Fernandes ${ }^{2 *}$ \\ ${ }^{1}$ Dental Intern, YMT Dental College, India \\ ${ }^{2}$ Department of Oral Biology, School of Dental Medicine, USA
}

Received: November 11, 2017; Published: November 30, 2017

*Corresponding author: Gabriela Fernandes, Department of Oral Biology, SUNY Buffalo, New York, USA; Email: gfernand@buffalo.edu

\begin{abstract}
Antimicrobial Peptides (AMPs) are present in the oral cavity in the form of defensins and human cathelicidin LL-37 (from neutrophil granules) and histatins along with pdefensins 1 and 2 (from salivary glands and gingival epithelial cells). The oral micro flora organisms that play an important role in the pathogenesis of periodontal disease are opportunistic pathogens, that are highly proteolytic and this activity is known to contribute to nutrient acquisition, tissue destruction and de-regulation of inflammatory responses. Furthermore, the production of proteases enables oral bacteria to evade killing by antimicrobial peptides, thus contributing to the virulence of such opportunistic pathogens, which could have implications for the use of antimicrobial peptides as therapeutic agents to treat periodontal disease. Hence, this review summarizes the suggestive role of AMPs in periodontal disease.
\end{abstract}

Keywords: Immunity; Anti-Microbial Peptides; Periodontitis

Abbreviations: AMPs: Antimicrobial Peptides, LAP: Lingual Antimicrobial Peptide, HNP: Human Neutrophil Peptide; hBD: Human BetaDefensins

\section{Introduction}

Humans often require a multilayered defense mechanism to function smoothly and combat micro-organisms and pathogens. The fundamental guarding complex for almost all human organisms comprises of innate immunity [1]. It is this defense mechanism that helps discern a wide variety of agents, known as pathogens, and distinguish them from the organism's own healthy tissue [1]. The oral cavity is a manifold interaction where sundry organisms, both commensal and destructive types, intercommunicate and escalate in the environment [2]. The noteworthy quality of the oral cavity lies in the presence of specialized interaction between tooth (hard tissue) presenting itself from the underlying gingival epithelium (soft tissue).

Ideally in the oral cavity, the tooth structure often encompasses a layer of pathogenic biofilm termed "Dental plaque," that compromises the surrounding epithelium via its incessant exposure to microorganisms [3]. This is when the comeback of the epithelium to these insults determines the overall condition of the gingival sulcus. It is evident that the oral epithelium works in several ways for the conservation of the underlying tissues. As a physical barricade, it can counter unbroken microbial oppositions from dental plaque by the production of chemokines, cytokines, and antimicrobial peptides (AMPs), which enhance inflammation and immune response in oral epithelial tissues [4]. These epithelial antimicrobial peptides are considered to be paramount for the innate immunity of the host [5].

AMPs are also prime contributors that enable the stabilization between health and disease in this complex ecosystem [6]. Exhibiting a wide spectrum of antimicrobial activity against grampositive and gram-negative bacteria, yeasts and certain viruses, they possess the ability to prevent various oral periodontal diseases including bacteria, fungal and viral infections [7]. The reaction involving multiple AMPs to a single pathogen of infection prevents the consequences of antimicrobial resistance. Several families of antimicrobial peptides have been studied in the oral cavity which includes $\alpha$-defensins, $\beta$-defensins, calprotectin, adrenomedullin, histatins, and cathelicidin [8]. The aim of this review paper is to view the crucial role of these molecules against periodontal diseases and its function in host immunity. The article also sheds light on the mechanism of action and the types of identified AMPs.

\section{Types of Anti-Microbial Peptides involved in Periodontitis}

The AMPs react to the periodontopathogenic bacteria in a synergistic manner, whereby they secrete chemical innate immunity 
signal molecules like interleukin, chemokine and cytokines that attract neutrophils at the site and caution the host response [7]. Conducive with the amount of microbial exposure, they also produce natural AMPs and proteins. By acting as an integral part of the hosts natural innate environment, the oral epithelium, polymorph nuclear leukocytes (neutrophils) and saliva, all concurrently and solitarily bestow to this response $[9,10]$. These responses involve several salivary antimicrobial peptides, the $\beta$-defensins manifested in the epithelium, the $\alpha$-defensins expressed in neutrophils, and the cathelicidin, LL-37, in both epithelium and neutrophils [11-13].

\section{Defensins}

The first AMPs identified in the oral epithelium were defensin, Lingual Antimicrobial Peptide (LAP) [14]. The defensin families are prominent AMPs that reside in the host environment, which include the alpha-defensins (human neutrophil peptide; HNP) and human beta-defensins (hBD) [15]. Defensins are stored in secretory granules, with expanding levels observed during periodontitis (Figure 1). Their mechanism of action involves destroying phagocytosed bacteria upon fusion with the secretory granules from the phagocytic vacuoles they reside in [16]. Being a part of the host's natural environment, expressed in gingiva, tongue, salivary glands and mucosa, they are present in conditions like oral inflammation, carcinomas, etc. Defensins have also shown to inhibit LPS-stimulated inflammatory responses in host cells, which is a primary causal mechanism in the pathogenesis of periodontal disease [16]. Defensins are allocated into subfamilies of $\alpha$ - and $\beta$-defensins. Human beta-defensins (hBD) are elementally revealed in epithelial cells, while alpha-defensin are predominantly expressed in neutrophils [17]. Segregated in terms of their cysteine motifs, dually both of them share a homogenous secondary structure, and are opulent in cationic residues [18,19].

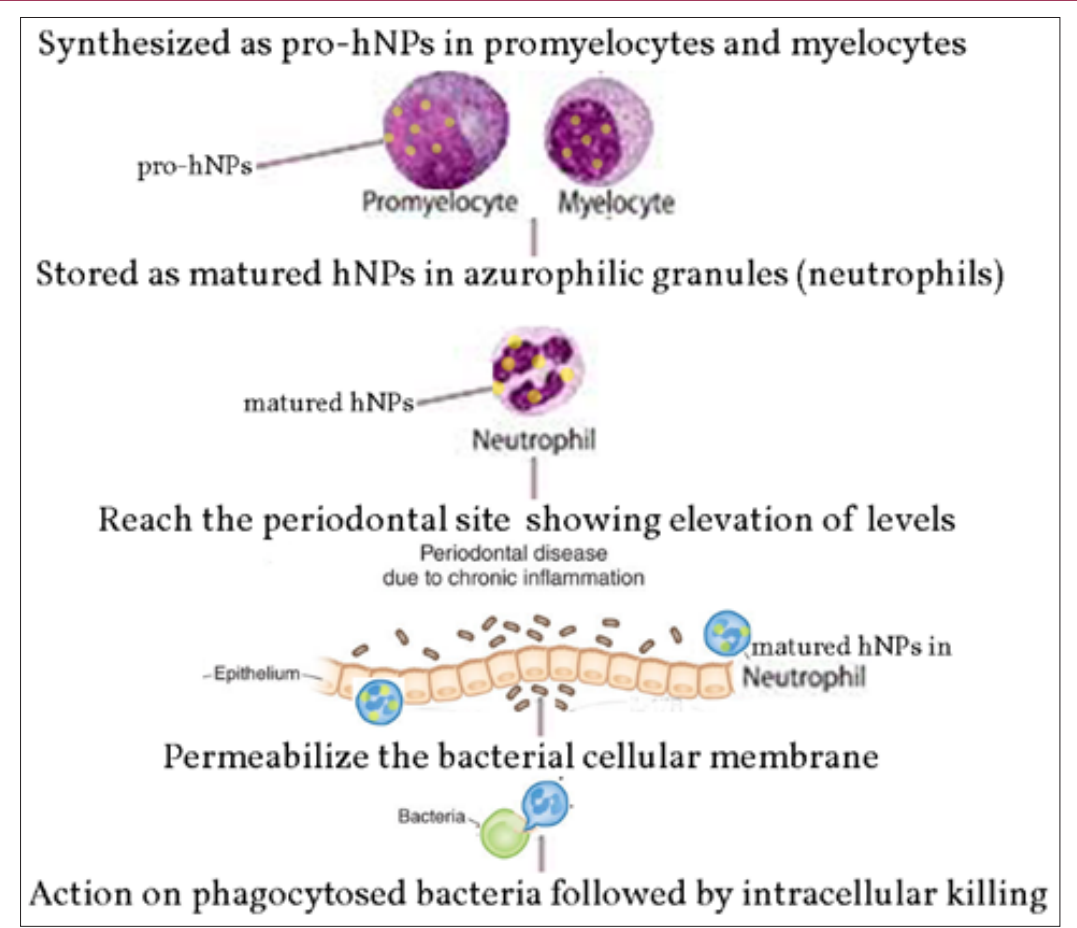

Figure 1: Mode of activation of hNPs in periodontal tissues.

In the $\alpha$-defensin subfamily, four of the six $\alpha$-defensins, human neutrophil peptide $-1,-2,-3$, and -4 , are fabricated and gathered in neutrophil granules while the other two $\alpha$-defensins, HD-5 and -6, are synthesized and stored in the granules of paneth cells, specialized epithelial cells at the crypts of Lieberkuhn of the small intestine $[17,20,21]$. In the $\beta$-defensin subfamily only hBD $-1,-2$ and -3 are substantially expressed in the oral cavity $[16,22]$. hBD-3 along with

Table 1: Summary of the role of defensins. the respective three mentioned above are markedly expressed in epithelial cells that encrust some tissues and organs, fundamentally skin [23]. In non-inflamed gingival tissues and gingival crevicular fluid, hBD-1 and hBD-2 have been expressed, with maximum levels at gingival margin [22]. Elevated levels of HNP1-3 have been noted in cases of periodontal infections, indicating a strong correlation See Table 1 for summary.

\begin{tabular}{|c|c|c|c|}
\hline Type of AMP & Site & Role & Association with oral diseases \\
\hline $\begin{array}{l}\text { alpha-defensins[7,14,24,39] } \\
\text { (human neutrophil peptide; hNP) } \\
\qquad \begin{array}{c}\text { hNP-1 } \\
\text { hNP-2 } \\
\text { hNP-3 }\end{array}\end{array}$ & $\begin{array}{c}\text { Neutrophils } \\
\text { Gingival crevicular fluid present in } \\
\text { the gingival sulcus. } \\
\alpha \text {-defensins, HNP-1-3, are } \\
\text { readily detected in the junctional } \\
\text { epithelium. }\end{array}$ & $\begin{array}{c}\text { Antibacterial } \\
\text { Antiviral } \\
\text { Antifungal }\end{array}$ & $\begin{array}{c}\text { Oral inflammation } \\
\text { Periodontal conditions } \\
\text { including chronic and aggressive } \\
\text { periodontitis showing gingival or } \\
\text { mucosal inflammation or loose } \\
\text { exfoliating teeth. } \\
\text { Oral cancer }\end{array}$ \\
\hline
\end{tabular}




\begin{tabular}{|c|c|c|c|}
\hline $\begin{array}{l}\text { hNP-4 } \\
\text { hNP-5 } \\
\text { hNP-6 }\end{array}$ & $\begin{array}{l}\text { Around } 99 \% \text { of hNP } 1-3 \text { is found in } \\
\text { the saliva. } \\
\text { hNP-4 levels are lower hNP-5 and } \\
\text { hNP- } 6 \text { are not found in the oral } \\
\text { cavity and are expressed in enteric } \\
\text { system. }\end{array}$ & $\begin{array}{l}\text { hNP-1 keeps a check on epithelial } \\
\text { cell adhesion and spread. }\end{array}$ & $\begin{array}{l}\text { hNP levels are seen to be higher } \\
\text { with oral diseases like oral lichen } \\
\text { plans, leukoplakia, SCC. }\end{array}$ \\
\hline $\begin{array}{l}\text { Human beta-defensins (hBD) } \\
\begin{array}{c}{[7,12,15,22,24,40]} \\
\text { Types: hBD-1 } \\
\text { hBD-2 } \\
\text { hBD-3 } \\
\text { hBD-4 }\end{array}\end{array}$ & $\begin{array}{l}\text { hBD-1 and hBD-2 : Found in supra } \\
\text { basal layers of stratified epithelium. } \\
\text { They are absent in junctional } \\
\text { epithelium. } \\
\text { hBD-3: It is expressed in } \\
\text { undifferentiated epithelial cells, } \\
\text { which is within the basal layer. } \\
\text { hBD-1 is constitutively expressed } \\
\text { hBD-2 and hBD-3 are unregulated } \\
\text { in inflamed skin and other } \\
\text { epithelial cells, by bacterial and } \\
\text { pro-inflammatory stimuli. Low } \\
\text { levels of unstimulated hBD-2 have } \\
\text { been observed. }\end{array}$ & $\begin{array}{c}\text { Principle AMPs holding major role } \\
\text { in initial innate comeback against } \\
\text { bacterial agents in tissues. Part of } \\
\text { protective barrier in periodontal } \\
\text { situations. } \\
\text { Anti-fungal } \\
\text { Anti-viral } \\
\text { Additionally, they play a role in } \\
\text { wound healing by rejuvenating the } \\
\text { damaged epithelium. } \\
\text { They function as both pro- } \\
\text { inflammatory and anti- } \\
\text { inflammatory agents in } \\
\text { pathogenesis of diseases. } \\
\text { Chemical appeal of dendritic cells } \\
\text { and t cells, macrophages } \\
\text { hBD-3 acts as a mediator to } \\
\text { signal the underlying cells in the } \\
\text { connective tissue. } \\
\text { Up-regulated levels hoods have } \\
\text { been observed in inflammatory } \\
\text { situations and infections. } \\
\text { Having higher levels at gingival } \\
\text { margins close to plaque, hBD-1 } \\
\text { and hBD-2 are expressed in non- } \\
\text { inflamed tissues. }\end{array}$ & $\begin{array}{l}\text { Infections and Inflammatory } \\
\text { situations like Dental Caries, } \\
\text { periodontitits, keratinocytic } \\
\text { differentiation, oral cancers }\end{array}$ \\
\hline
\end{tabular}

\section{Cathelicidin (LL-37)}

Used markedly as one of the predominant identifying tools in inflammatory periodontal disorders, this class of AMPs incorporates a mature peptide and cathelin domain. It is a multifunctional peptide, comprising of 37 amino acids [24]. Active against gram positive and gram negative bacterias, it directly binds to the LPS of bacterial cells, and is native to the oral cavity in several sites, including the buccal and tongue mucosa, gingival crevicular

fluid [24]. By activating antigen-presenting cells, it presents as a hemoattractant for immune cells, including monocytes, $\mathrm{T}$ cells, etc. There is a specific correlation amongst multiplication in LL-37 levels and periodontal inflammation [25-28]. It is also known to cause an elevation in mucosal thickness in the gingiva. Furthermore, studies have also demonstrated its tissue specific effects on cancer cells $[27,28]$. Their mode of action involves intracellular killing of the phagosomes after phagocytosis of the bacteria, where the AMP in the neutrophil is severed into a fully developed peptide (Table 2).

Table 2: Summary of the role of Cathelicidin.

\begin{tabular}{|c|c|c|}
\hline Type of AMP & Site & Role \\
\hline Cathelicidin (LL-37) [25,27,41-46] & $\begin{array}{c}\text { Found in neutrophils as well as } \\
\text { epithelial cells Saliva }\end{array}$ & $\begin{array}{c}\text { Primary antibacterial- Gram } \\
\text { positive and gram negative } \\
\text { bacterias Diagnostic tool in } \\
\text { Inflammatory periodontal } \\
\text { disorders }\end{array}$ \\
$\begin{array}{c}\text { Gingival crevicular fluid in gingival } \\
\text { sulcus }\end{array}$ & $\begin{array}{c}\text { Increased levels observed in } \\
\text { chronditions. Tissue specific in terms } \\
\text { of cancer cells }\end{array}$ \\
\hline
\end{tabular}

\section{Histatins}

These AMPs are exclusively resided in the salivary glands, i.e. parotid and submandibular salivary duct cells. Histamine 1, 3 and 5 are found to be predominant of the total histatin proteins (85\%) in the saliva [29-32]. They have a major role in fungicidal activity, having a noteworthy role in oral candidiasis restraint, especially histatin-5, which is the most significantly active against candida species as well as bactericidal activities against Porphyromonas gingivalis and Streptococcus mutans, which play a key role in the etiopathogenesis of periodontal disease and dental caries ,respectively [30,32]. Significant linkage occurs between xerostomia and oral candidiasis. It is also noteworthy that the antifungal action is shared between alpha-defensin and histatin, which require ATP transport found in active mitochondria.

\section{Secretory Leuko Protease Inhibitor (SLPI)}

Another AMP identified from the parotid salivary gland is SLPI. Manifested in neutrophils, epithelial cells and salivary glands, this 
protein suggests anti-inflammatory action at the site of infection [33]. Supplementary to having fungicidal action, it has shown to inhibit contamination of human monocytes and is also conveyed in oral tumor tissues as well as inhibition of the HIV virus $[34,35]$. SLPI is associated with wound repair and its expression is elevated following wound healing $[35,36]$. The elevated quantity of SLPI following periodontal treatment is an evidence of inflammation resolution activities [36].

\section{Summary}

The capacity of these inborn antibiotics is only at its inception of its recognition, as amplified natural announcement or as novel relieving agents $[8,37]$. This class of proteins is a captivating target for periodontal diseases [37]. In times of periodontal disease, Table 3: Significance of AMPs.
AMPs amalgamate with other inflammatory proteins and maintain inflammatory molecules and pathways. It can be concluded that salivary AMPs have a prospective capacity to be recognized as initial markers of periodontal infections [38]. Thus, a dual approach is mandatory to comprehend the task of hosts' immunity in response to, against periodontitis [37]. This involves more comprehensive statistics about HNP and hBD, LL-37, and other oral antimicrobial peptides and proteins, along with their mode of action and clinical significance [38-50]. These peptides are peculiar in keeping the level of bacteria in control, having distinctive as well as dual roles in maintaining oral health. Not only can they act as diagnostic or prognostic biomarkers, but also the enhancement of new peptide agents can be a signaling method for future investigation and testing (Table 3).

\begin{tabular}{|c|c|c|}
\hline \multicolumn{3}{|c|}{ Clinical Significance of Amps In Certain Conditions } \\
\hline Disease & Manifestations & Observations \\
\hline Morbus Kostmann disease [47] & $\begin{array}{l}\text { Austere congenital neutropenia with severe } \\
\text { periodontitis. }\end{array}$ & $\begin{array}{l}\text { Deficiency in LL-37 in neutrophils, plasma, and } \\
\text { saliva } \\
\text { Alpha-defensins deficiency ( by 70\% ) } \\
\text { Normal Lactoferrin levels }\end{array}$ \\
\hline $\begin{array}{c}\text { Papillon-Lefe`vre syndrome }[48,49] \\
\text { Haim-Munk syndrome [50] }\end{array}$ & $\begin{array}{l}\text { Palm plantar keratoderma and severe } \\
\text { periodontitis }\end{array}$ & Allelic mutations of the cathepsin C(CTSC) gene \\
\hline
\end{tabular}

Moreover, Antimicrobial peptides are potentially important as novel therapeutic agents against periodontal disease diagnosis and potential treatment and probably show most immediate promise for development as topical adjuvant agents in conjunction with conventional periodontal therapy in the treatment of periodontal disease. This makes them promising for oral diseases, as topical application of antimicrobial agents is easy and appropriate, and their use would not contribute to resistance to antibiotics normally used in treatment of more life-threatening bacterial infections. All these findings will have direct implications for new understanding of oral innate immune responses and the development of potential new and innovative therapeutic interventions for periodontal disease.

\section{References}

1. Deschamps M, Quintana-Murci L (2016) Innate immunity and human diseases: from archaic introgression to natural selection. Medecine sciences 32(12): 1079-1086.

2. Bowden GH, Hamilton IR (1998) Survival of oral bacteria. Critical reviews in oral biology and medicine $9(1)$ : 54-85.

3. Guggenheim B (1974) the role of microbial dental plaque in the etiology of dental caries and periodontal diseases. Pathologia ET microbiologia 40(3): 207-226.

4. Marsh PD (2004) Dental plaque as a microbial biofilm. Caries research 38(3): 204-211.

5. Brogden KA, Johnson GK, Vincent SD, Abbasi T, Vali S (2013) Oral inflammation, a role for antimicrobial peptide modulation of cytokine and chemokine responses. Expert review of anti-infective therapy 11(10): 1097-1113.

6. Bals R (2000) Antimicrobial peptides and peptide antibiotics. Medizinische Klinik 95(9): 496-502.
7. Dale BA, Kimball JR, Krisanaprakornkit S, Roberts F, Robinovitch M, et al. (2001) Localized antimicrobial peptide expression in human gingiva. Journal of periodontal research 36(5): 285-294.

8. Park Y, Hahm KS (2005) Antimicrobial peptides (AMPs): peptide structure and mode of action. Journal of biochemistry and molecular biology 38(5): 507-516.

9. Peyret-Lacombe A, Duplan H, Watts M, Charveron M, Brunel G (2007) Antimicrobial peptide modulation in a differentiated reconstructed gingival epithelium. Cell and tissue research 328(1): 85-95.

10. Suwandecha T, Srichana T, Balekar N, Nakpheng T, Pangsomboon K (2015) Novel antimicrobial peptide specifically active against Porphyromonas gingivalis. Archives of microbiology 197(7): 899-909.

11. Jonsson D, Nilsson BO (2012) the antimicrobial peptide LL-37 is antiinflammatory and proapoptotic in human periodontal ligament cells. Journal of periodontal research 47(3): 330-335.

12. Ozturk A, Famili P, Vieira AR (2010) the antimicrobial peptide DEFB1 is associated with caries. Journal of dental research 89(6): 631-636.

13. Turkoglu O, Kandiloglu G, Berdeli A, Emingil G, Atilla G (2011) Antimicrobial peptide hCAP-18/LL-37 protein and mRNA expressions in different periodontal diseases. Oral diseases 17(1): 60-67.

14. Mizukawa N, Sugiyama K, Ueno T, Mishima K, Takagi S, et al. (1999) Defensin-1, an antimicrobial peptide present in the saliva of patients with oral diseases. Oral diseases 5(2): 139-142.

15. Makeudom A, Supanchart C, Montreekachon P, Khongkhunthian S, Sastraruji T, et al. (2017) the antimicrobial peptide, human betadefensin-1, potentiates in vitro osteoclastogenesis via activation of the p44/42 mitogen-activated protein kinases. Peptides 95: 33-39.

16. Mizukawa N, Sugiyama K, Ueno T, Mishima K, Takagi S, et al. (1999) Levels of human defensin-1, an antimicrobial peptide, in saliva of patients with oral inflammation. Oral surgery, oral medicine, oral pathology, oral radiology, and endodontics $87(5): 539-543$. 
17. Batoni G, Maisetta G, Esin S, Campa M (2006) Human beta-defensin-3: a promising antimicrobial peptide. Mini reviews in medicinal chemistry 6(10): 1063-1073.

18. Yamaguchi Y, Ouchi Y (2012) Antimicrobial peptide defensin: identification of novel isoforms and the characterization of their physiological roles and their significance in the pathogenesis of diseases. Proceedings of the Japan Academy Series B, Physical and biological sciences 88(4): 152-166.

19. Rahman M, Tsuji N, Boldbaatar D, Battur B, Liao M, et al. (2010) Structural characterization and cytolytic activity of a potent antimicrobial motif in longicin, a defensin-like peptide in the tick Haemaphysalis longicornis. The Journal of veterinary medical science / the Japanese Society of Veterinary Science 72(2): 149-156.

20. Lin P, Li Y, Dong K, Li Q (2015) The Antibacterial Effects of an Antimicrobial Peptide Human beta-Defensin 3 Fused with Carbohydrate-Binding Domain on Pseudomonas aeruginosa PA14. Current microbiology 71(2): 170-176.

21. Viljakainen L, Pamilo P (2008) Selection on an antimicrobial peptide defensin in ants. Journal of molecular evolution 67(6): 643-652.

22. Sahasrabudhe KS, Kimball JR, Morton TH, Weinberg A, Dale BA (2000) Expression of the antimicrobial peptide, human beta-defensin 1, in duct cells of minor salivary glands and detection in saliva. Journal of dental research 79(9): 1669-1674.

23. Bayer A, Lammel J, Tohidnezhad M, Lippross S, Behrendt P, et al. (2017) The Antimicrobial Peptide Human Beta-Defensin-3 Is Induced by Platelet-Released Growth Factors in Primary Keratinocytes. Mediators of inflammation 2017: 6157491.

24. Tao R, Jurevic RJ, Coulton KK, Tsutsui MT, Roberts MC, et al. (2005) Salivary antimicrobial peptide expression and dental caries experience in children. Antimicrobial agents and chemotherapy 49(9): 3883-3888.

25. Kittaka M, Shiba H, Kajiya M, Ouhara K, Takeda K, et al. (2013) Antimicrobial peptide LL37 promotes vascular endothelial growth factor-A expression in human periodontal ligament cells. Journal of periodontal research 48(2): 228-234.

26. Ramos R, Silva JP, Rodrigues AC, Costa R, Guardão L, et al. (2011) Wound healing activity of the human antimicrobial peptide LL37. Peptides 32(7): 1469-1476.

27. Jia J, Zheng Y, Wang W, Shao Y, Li Z, et al. (2017) Antimicrobial peptide LL37 promotes YB-1 expression, and the viability, migration and invasion of malignant melanoma cells. Molecular medicine reports 15(1): 240248.

28. Pinegin BV, Pashenkov MV, Kulakov VV, Murugin VV, Zhmak MN (2015) Complexes of DNA with the Antimicrobial Peptide LL37 Augment NK Cell Functions by Inducing Type I Interferon Production from Circulating Monocytes and Plasmacytoid Predendritic Cells. Journal of interferon \& cytokine research: the official journal of the International Society for Interferon and Cytokine Research 35(11): 850-858.

29. Melino S, Santone C, Di Nardo P, Sarkar B (2014) Histatins: salivary peptides with copper (II)- and zinc(II)-binding motifs: perspectives for biomedical applications. The FEBS journal 281(3): 657-672.

30. Tsai H, Bobek LA (1998) Human salivary histatins: promising antifungal therapeutic agents. Critical reviews in oral biology and medicine 9(4): 480-497.

31. Iontcheva I, Oppenheim FG, Troxler RF (1997) Human salivary mucin MG1 selectively forms heterotypic complexes with amylase, proline-rich proteins, statherin, and histatins. Journal of dental research 76(3): 734743.

32. Xu T, Levitz SM, Diamond RD, Oppenheim FG (1991) Anticandidal activity of major human salivary histatins. Infection and immunity 59(8): 2549-2554.

33. Reviglio VE, Sambuelli RH, Olmedo A, Falco M, Echenique J, et al. (2007) Secretory leukocyte protease inhibitor is an inducible antimicrobial peptide expressed in Staphylococcus aureus endophthalmitis. Mediators of inflammation 2007: 93857.

34. Thakar M, Patil R, Shukre S, Bichare S, Kadam P, et al. (2014) Short communication: genital tumor growth factor-beta1 levels in HIVinfected Indian women are associated with reduced levels of innate antimicrobial products and increased HIV shedding. AIDS research and human retroviruses 30(7): 648-653.

35. Persson LJ, Aanerud M, Hardie JA, Roy Miodini Nilsen, Per S Bakke, et al. (2017) Antimicrobial peptide levels are linked to airway inflammation, bacterial colonisation and exacerbations in chronic obstructive pulmonary disease. The European respiratory journal 49: 1601328.

36. Nakamura-Minami M, Furuichi Y, Ishikawa K, Mitsuzono-Tofuku Y, Izumi Y (2003) Changes of alpha1-protease inhibitor and secretory leukocyte protease inhibitor levels in gingival crevicular fluid before and after nonsurgical periodontal treatment. Oral diseases 9(5): 249-254.

37. Da Silva BR, De Freitas VA, Nascimento-Neto LG, Carneiro VA, Arruda FV, et al. (2012) Antimicrobial peptide control of pathogenic microorganisms of the oral cavity: a review of the literature. Peptides 36(2): 315-321.

38. Sato FS, Rompen E, Heinen E (2009) Antimicrobial peptide in dentisty. Literature review. Revue medicale de Liege 64: 645-650.

39. Jin G, Kawsar HI, Hirsch SA, Zeng C, Jia X, et al. (2010) an antimicrobial peptide regulates tumor-associated macrophage trafficking via the chemokine receptor CCR2, a model for tumorigenesis. PloS one 5(6): e10993.

40. Chung WO, Hansen SR, Rao D, Dale BA (2004) Protease-activated receptor signaling increases epithelial antimicrobial peptide expression. Journal of immunology 173(8): 5165-5170.

41. Liu Z, Yuan X, Liu M, Fernandes G, Zhang Y, et al. (2017) Antimicrobial Peptide Combined with BMP2-Modified Mesenchymal Stem Cells Promotes Calvarial Repair in an Osteolytic Model. Molecular therapy: the journal of the American Society of Gene Therapy.

42. Zhang LJ, Sen GL, Ward NL, Johnston A, Chun K, et al. (2016) Antimicrobial Peptide LL37 and MAVS Signaling Drive Interferon-beta Production by Epidermal Keratinocytes during Skin Injury. Immunity 45(1): 119-130.

43. Gasim A (2014) Cathelicidin antimicrobial peptide as a serologic marker and potential pathogenic factor in antineutrophil cytoplasmic antibodyassociated vasculitis. Arthritis research \& therapy 16: 105.

44. Kittaka M, Shiba H, Kajiya M, Fujita T, Iwata T, et al. (2013) the antimicrobial peptide LL37 promotes bone regeneration in a rat calvarial bone defect. Peptides 46: 136-142.

45. Gustafsson A, Sigel S, Ljunggren L (2010) the antimicrobial peptide LL37 and its truncated derivatives potentiates proinflammatory cytokine induction by lipoteichoic acid in whole blood. Scandinavian journal of clinical and laboratory investigation 70(7): 512-518.

46. Kajiya M, Shiba H, Komatsuzawa H, Ouhara K, Fujita T, et al. (2010) the antimicrobial peptide LL37 induces the migration of human pulp cells: a possible adjunct for regenerative endodontics. Journal of endodontics 36(6): 1009-1013.

47. Putsep K, Carlsson G, Boman HG, Andersson M (2002) Deficiency of antibacterial peptides in patients with morbus Kostmann: an observation study. Lancet 360: 1144-1149.

48. Roberts H, White P, Dias I, McKaig S, Veeramachaneni R, et al. (2016) Characterization of neutrophil function in Papillon-Lefevre syndrome. Journal of leukocyte biology 100(2): 433-444.

49. Sorensen OE, Clemmensen SN, Dahl SL, Østergaard O, Heegaard NH, et al. (2014) Papillon-Lefevre syndrome patient reveals speciesdependent requirements for neutrophil defenses. The Journal of clinical investigation 124(10): 4539-4548.

50. Hart TC, Hart PS, Michalec MD, Zhang Y, Firatli E, et al. (2000) HaimMunk syndrome and Papillon-Lefevre syndrome are allelic mutations in cathepsin C. Journal of medical genetics 37(2): 88-94. 


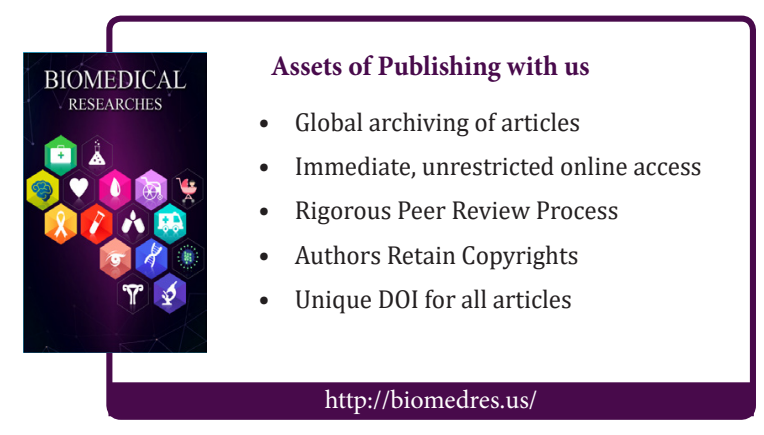

